\title{
Conhecer é dar forma: a tradução em Vilém Flusser e Walter Benjamin
}

\author{
Rafael Miguel Alonso ${ }^{1}$ \\ Faculdade de Comunicação e Cinema, Sociedade Educacional de Santa Catarina, Joinville, SC, Brasil
}

Resumo: O objetivo do presente ensaio é, a partir de uma aproximação teórica entre dois filósofos judeus, Vilém Flusser e Walter Benjamin, postular a tradução enquanto teoria do conhecimento. Em ambos os pensadores, a teoria da língua complementa a teoria da tradução, constituindo uma estratégia epistemológica que não separa convenção e expressão, método e conteúdo. Conhecer é abrir mão da integralidade e da objetividade do mundo, ao mesmo tempo que o desafio do sujeito conhecedor é o de forjar uma forma que não abandone a materialidade. Factualidade esta que pode ser a da própria palavra, já que a literatura, assim como as ciências, estabelecem-se discursivamente. Além de conceitos-chaves nas teorias de Flusser e Benjamin, como os de tradução, língua, realidade e alegoria, o ensaio recorre, ainda, e principalmente, a João Guimarães Rosa, Octavio Paz e Eduardo Viveiros de Castro.

Palavras-chave: Benjamin; Flusser; Tradução; Língua; Teoria do conhecimento.

Title: Cognizing is to give a form: the translation in Vilém Flusser and Walter Benjamin

Abstract: The aim of this essay is, from a theoretical approach between two Jewish philosophers, Vilém Flusser and Walter Benjamin, postulate the translation as a theory of knowledge. In both thinkers, the theory of language complements the theory of translation, constituting an epistemological strategy that does not separate convention and expression, method and content. Knowing is to give up the integrality and objectivity of the world, while the challenge of the knowing subject is to forge a form that does not abandon materiality. This factuality may be that one of the word itself, since literature, as well as the sciences, establish themselves discursively. In addition to key concepts in the theories of Flusser and Benjamin, such as translation, language, reality and allegory, the essay also resorts, mainly, to João Guimarães Rosa, Octavio Paz and Eduardo Viveiros de Castro.

Keywords: Benjamin; Flusser; Translation; Language; Theory of knowledge.

I.

O filósofo Vilém Flusser, praguense e brasileiro, faz da tradução não apenas um motivo de reflexão, mas um método de trabalho. Ele escreve em quatro línguas (alemão, francês, inglês e português - pouco ou nada em tcheco) e encontra na autotradução o modo mais

\footnotetext{
${ }^{1}$ Mestre e Doutor em Literatura pela Universidade Federal de Santa Catarina, UFSC. Professor dos cursos de Comunicação e Cinema da Unisociesc, em Joinville-SC. Orcid: https://orcid.org/0000-00017253-6814

E-mail: rafamalonso@gmail.com
} 
efetivo de autocrítica. As muitas versões de um texto de Flusser não consistem de acréscimos ou subtrações, reformulações ou reconsiderações, mas de traduções para outras línguas. Flusser escreve, inicialmente, na língua em que anseia publicar, então força o texto a atravessar, e ser atravessado, pelas outras línguas que domina, até fazê-lo retornar, diferido e desdobrado, à língua desejada.

Judeu como Walter Benjamin, Flusser reúne, em si, o gesto da tradução e a errância do migrante. Vilém foge de Praga com a família da futura esposa em 1939, e, depois de um ano na Inglaterra, chega ao Brasil, onde permaneceria por pouco mais de três décadas. Seus parentes todos são assassinados pelo regime nazista. Para quem vive sem chão, ou bodenlos, sem fundamento, termos que acompanham os títulos de sua biografia ${ }^{2}$ e de sua autobiografia ${ }^{3}$, articular-se em várias línguas não é, fundamentalmente, forjar um conceito filosófico, mas estabelecer um caminho possível de pensamento - uma estratégia de sobrevivência.

O migrante plurilíngue sabe que a realidade está atravessada pela língua e, na impossibilidade de manter-se fiel à língua própria (materna), não encontra estabilidade em realidade nenhuma. Flusser, como tantos outros migrantes, judeus ou não, tem os laços com o familiar (língua, país, família) rompidos forçosamente. Ainda assim, ele faz notar que a condição de estrangeiro é, no fundo, a de todo vivente, já que os discursos que advogam em nome do que é próprio (raça, pátria, religião) não tardam a recair em fascismos e nacionalismos. Desta forma, o problema da tradução é o da liberdade. "O problema da tradução é pois o problema da transcendência, do abandono da prisão, do estar além de todos os modelos. Em outras palavras: é o problema da liberdade" ${ }^{4}$.

Talvez o estudo mais completo sobre a tradução em Flusser seja o de Rainer Guldin, Pensar entre línguas: a teoria da tradução em Vilém Flusser ${ }^{5}$. Para Guldin, um dos méritos de Flusser - e que o torna atual - foi ter refletido sobre as implicações da tradução não somente em termos de crítica linguística e cultural, mas também em termos de teoria do conhecimento: "[...] e isso antes do desconstrucionismo e da proliferação de conceitos de tradução nos discursos argumentativos das Ciências Humanas e Sociais" 6 .

O que Flusser teria visto, ou antevisto, ainda no princípio da década de 1960, foi que a argumentação da filosofia ocidental derivou da "sistematização das línguas para as linguagens da sistematização"7. Toda tentativa de sistematização é um esforço de ajustar a língua, em

\footnotetext{
${ }^{2}$ BERNARDO, Gustavo; GULDIN, Rainer. O homem sem chão. A biografia de Vilém Flusser. São Paulo: Annablume, 2017.

${ }^{3}$ FLUSSER, Vilém. Bodenlos: uma autobiografia filosófica. São Paulo: Annablume, 2007. O texto foi redigido no começo dos anos 1970, em alemão, e publicado postumamente, no mesmo idioma, em 1992. A edição aqui mencionada está em português e foi redigida pelo próprio Flusser.

${ }^{4}$ FLUSSER, Vilém. “Da tradução". In: Cadernos Brasileiros, São Paulo, outubro de 1968, p. 76.

${ }^{5}$ GULDIN, Rainer. Pensar entre línguas: a teoria da tradução em Vilém Flusser. Trad. Murilo Jardelino e Clélia Barqueta. São Paulo: Annablume, 2010.

${ }^{6}$ Idem, p. 11.

${ }^{7}$ Idem, p. 86.
} 
sua relação com outras línguas, a um único sistema. O problema da sistematização é, portanto, um problema de tradução. Para Flusser, a tradução é a contraparte não metafísica da procura pelo sentido e pelo significado. Uma transcendência totalizadora - divina, científica, historicamente linear e progressiva - dá lugar a uma transcendência imanente ou estrutural:

\begin{abstract}
Uma teoria da tradução urge. Faz parte da procura de sentido e significado que nos caracteriza. Este é o desafio lançado na segunda metade do século 20: sentido e sem sentido, significado e absurdo. Uma problemática religiosa. A segunda metade do século 20 retorna à religiosidade do lado formal, do lado da estrutura. Após quinhentos anos de férias coletivas volta o ocidente a engajar-se. Propelido para tanto pelo sem sentido e pela falta de significado. E uma teoria da tradução é uma peça indispensável na marcha de retorno. É pois neste contexto que deve ser formulada ${ }^{8}$.
\end{abstract}

II.

A proposta deste ensaio, portanto, é pensar a teoria da tradução de Flusser, em sintonia com a de Walter Benjamin, nos termos de uma teoria do conhecimento. A tradução, para além da transposição de uma língua a outra, constitui-se como pressuposto epistemológico de primeira necessidade. Os gestos de pesquisar, conhecer e publicar demandam um esforço de tradução, o que não se confunde com a divulgação científica, ascendente a partir do começo do século XX e que se baseia no tornar vulgar a informação, tendo em vista a transmissão hierarquizada do saber do mestre ao ignorante. Jacques Rancière desmonta criticamente este movimento ao escancarar que o hiato que se abre entre o expert e o leigo não parte de uma falta (de um não-saber) a ser suprida por aquele que sabe menos, mas é alimentado por aquele que supostamente sabe mais a fim de manter as estruturas do saber, que são também estruturas de poder, como cansou de apontar Michel Foucault, intactas ${ }^{9}$.

Traduzir, deste modo, não é transpor um pensamento complexo em palavras simples, mas traduzir o mundo em símbolos, palavras ou imagens, que permitam àquele que articula pensamentos conferir sentido à própria existência em parceria com um outro, ou outros, que se disponham a ler estes símbolos. O mundo, em si, não é nada. O mundo não preexiste aos esforços que visam articulá-lo. Por isso que a realidade, para Flusser, e essa é a tese central de seu primeiro livro publicado, Língua e Realidade ${ }^{10}$, de 1963, escrito originalmente em

\footnotetext{
${ }^{8}$ FLUSSER, Vilém. "Problemas da tradução". Inédito. Vilém Flusser Archiv.

${ }^{9}$ Ver: RANCIÈRE, Jacques. O mestre ignorante: cinco lições sobre a emancipação intelectual. Trad. Lílian do Valle. Belo Horizonte: Autêntica, 2002. FOUCAULT, Michel. A ordem do discurso. Trad. Laura Fraga Sampaio. 21 ed. São Paulo: Loyola, 1996.

${ }^{10}$ FLUSSER, Vilém. Língua e Realidade. São Paulo: Annablume, 2007.
} 
português, está dividida entre as palavras em estado nascente (os dados brutos ou dados objetivos) e as palavras já escritas ou faladas.

Pensar é traduzir pensamentos em palavras e imagens, embora, em Flusser, por mais que ele passe a se dedicar profundamente ao estudo das imagens técnicas no retorno à Europa, pensar é refletir sobre a estrutura das várias línguas, uma vez que a realidade está articulada linguisticamente. Até mesmo os aparelhos, como a máquina fotográfica, e isto aparece em Filosofia da Caixa Preta ${ }^{11}$, de 1983, seu best-seller, são, no limite, textos científicos aplicados. A leitura das imagens técnicas demandaria, neste sentido, a leitura dos textos que contribuíram para a produção dos aparelhos, os seus programas, sendo a tradução e a retradução constante entre texto e imagem o método mais indicado para compreender o contemporâneo. Flusser, em síntese, vislumbra uma forma política de tecnoimaginação, ou uma epistemologia que parta da superficialidade - das imagens e do corpo.

Benjamin defende posição semelhante ainda nos anos 1930, quando escreve a primeira versão do célebre ensaio "A obra de arte na era de sua reprodutibilidade técnica"12. Para o filósofo, a produção de imagens do cinema encarnava o ponto de vista do psicótico e do sonhador. Esta natureza que fala à câmara, que é diferente da que fala ao olhar, poderia tanto abrir o campo do inconsciente ótico que, através dos processos sensoriais de enervação permitidos pelo cinema, ativaria a consciência de classe das massas, quanto poderia dar vasão à criação de mitos coletivos inconscientes, como o Mickey Mouse, espécie de contraparte atenuada da apropriação mais nefasta dos meios técnicos pelo fascismo, a sua utilização para a guerra. O que estava em jogo, para Benjamin, era uma forma de conhecimento que se desse pela distração, que conjugasse inconsciente ótico e inconsciente pulsional.

No caso de Benjamin, implica dizer que o pensamento é alegórico. Alegorias são constelações provisórias de sentido que, ao mesmo tempo em que tornam o mundo imaginável, confessam a impossibilidade de conferir um significado último a este mesmo mundo. O gesto de conhecer, que aqui está subsumido ao gesto de traduzir, é monstruoso barroco, também - porque depende da assunção de duas premissas diabólicas ou mefistofélicas.

Em primeiro lugar, a admissão de que, como postula Friedrich Nietzsche, não apenas Deus está morto, mas o ponto centralizador antes ocupado pela imagem da transcendência continua vazio: a ruína da modernidade é também a impossibilidade de estabelecer um pensamento totalizador - é o abandono da completude. As pontas das igrejas medievais, que antes apontavam para o alto do céu, agora apontam para o nada. Flusser, em livro até pouco tempo inédito, escrito nos anos 1960 , afirma que a modernidade opera a passagem dos gestos

\footnotetext{
${ }^{11}$ FLUSSER, Vilém. Filosofia da Caixa Preta: ensaios para uma futura filosofia da fotografia. São Paulo: Annablume, 2011.

${ }^{12}$ BENJAMIN, Walter. "A obra de arte na era de sua reprodutibilidade técnica". In: BENJAMIN, Walter. Magia e técnica, arte e política: ensaios sobre literatura e história da cultura. Trad. Sergio Paulo Rouanet. São Paulo: Brasiliense, 1994, p. 165-196.
} 
centrípetos (voltados a um ponto comum, então identificado com a figura divina) para os gestos centrífugos (que, conforme indica a etimologia, fogem do centro) ${ }^{13}$.

Em segundo lugar, o reconhecimento de que, se pensar é traduzir o mundo em símbolos, o pensamento não apenas recorta o real, no sentido da parcialidade inevitável, como também relativiza a existência inteiramente apreensível de um real, chamado por Flusser, em suas teorizações sobre a língua, de dados brutos ou elementos concretos.

Cabe forjar, como faz Benjamin em suas "Teses sobre o conceito de história"14, uma forma de verdade, de real-idade, que poderíamos chamar de histórica, que prescinda do elemento necessariamente factual. Refletir sobre o passado não é, como afirma Benjamin, conta-lo tal como ele supostamente ocorreu, mas transformá-lo em narrativa quando este aparece à rememoração, no momento do perigo. Pensar uma epistemologia da alegoria, como sugere Benjamin, não implica na perda da capacidade política do historiador materialista. Se traduzir não é vulgarizar, pensar alegoricamente também não significa fantasiar a realidade. A ficção não é meio auxiliar de conhecimento, mas ferramenta inerente à episteme, como analisa Hans Vaihinger em clássico tratado de $1911^{15}$, e como não deixa de comprovar a literatura de Franz Kafka.

No ensaio sugestivamente intitulado "Exílio e Criatividade", Flusser descreve a condição de exilado aproveitando-se de um conceito fundamental na filosofia de Martin Heidegger: “Tudo passa a ser percebido e demonstrável: 'monstroso'. Os gregos chamavam tal descoberta pelo termo 'a-letheia', o qual traduzimos por 'verdade'. O exilado foi empurrado rumo a verdade"16. Toda demonstração, ou seja, toda exposição que se deseja clara, é sempre monstruosa, ideia que Jacques Derrida explora, nos seminários "A besta e o soberano", ao escancarar o caráter fabular do discurso político: "como queríamos demonstrar"17.

O dado bruto, o aspecto concreto do mundo, só passa a fazer sentido quando articulado linguisticamente. Flusser não rechaça a existência de uma realidade sensorial, que falaria antes ao corpo do que ao intelecto, mas esclarece que essa realidade difusa acedia os sentidos para ser convertida em língua. Em igual modo, Benjamin pede que o homem moderno (espectador do cinema ou trabalhador fabril) intercepte os efeitos de choque da atualidade através de uma memória ativa.

\footnotetext{
${ }^{13}$ FLUSSER, Vilém. Até a terceira e quarta geração. Vilém Flusser Archiv. No final de 2017, a Editora É Realizações, sob a coordenação de Rodrigo Maltez Novaes e Rodrigo Petrônio, publicou o livro em dois volumes com o título de Gerações: $O$ último juízo. O "box" inaugurou a publicação das obras completas de Flusser. $O$ texto a que se faz referência aqui é o do manuscrito que se encontra no Vilém Flusser Archiv, em Berlim, acessado também em 2017.

${ }^{14}$ BENJAMIN, Walter. "Sobre o conceito de História". In: BENJAMIN, Walter. Op. cit., p. 222-234.

${ }^{15}$ VAIHINGER, Hans. A filosofia do como se: sistema das ficções teóricas, práticas e religiosas da humanidade, na base de um positivismo idealista. Trad.: Johannes Kretschmer. Chapecó: Argos, 2011. ${ }^{16}$ FLUSSER, Vilém. "Exílio e criatividade". In: Viagem Brasileira, novembro de 1984.

${ }^{17}$ DERRIDA, Jacques. Seminario La bestia y el soberano: volumen 2001-2002. Trad. Cristina de Peretti e Delmiro Rocha. Buenos Aires: Manantial, 2010.
} 
A Flusser interessa sobretudo esse lugar da articulação, esse limiar, não apenas por um impulso racionalista a quem importaria o mundo organizado logicamente em detrimento da experiência imediata dos sentidos, mas por considerar que a experiência autêntica localiza-se justamente neste ponto em que o mundo vacila entre nada e palavra, entre nada e nonada, que nada mais é do que o ponto da articulação poética, no qual a palavra, ainda que cristalizada em imagem, ainda é larva, e que é também o ponto que retém a principal qualidade do sábio narrador benjaminiano, aquele que consegue imprimir na história a substância viva da experiência ${ }^{18}$.

Como o poema, a história não é contada com fatos, mas com palavras. Avançar ou regredir até o ponto em que o pensamento se articula não é buscar por uma origem perdida, que fundaria um tempo e uma história, mas procurar pelo lugar impossível onde nascem as palavras. Não o "berço da civilização", mas a espuma de Afrodite, com a viscosidade do esperma de Urano. É vasculhar no informe o surgimento das formas.

Pode ser, ainda, a regressão onírica que Benjamin elogia no surrealismo ${ }^{19}$ ou a memória involuntária de Marcel Proust, que permite às coisas que apareçam auraticamente e de modo não deliberado, diferentemente da reprodução técnica, que procura objetivamente o semelhante no mundo ${ }^{20}$.

Colocar-se no limiar, portanto, não é buscar a posição privilegiada, mas é reconhecer que somente a partir deste lugar-limite é que se pode falar autenticamente. Conhecer se torna um gesto diabólico quando o conhecedor recusa toda e qualquer totalidade, quando abre mão da inteireza do mundo divino e aceita, sem pesar, que cada gesto de conhecimento forja um fragmento de mundo, uma imagem artificiosa e parcial. Uma alegoria.

O que o Diabo, porém, propositalmente omite, é que as categorias que elaboro para conhecer e dar sentido ao mundo tornam-se, com este esforço, as categorias que garantem a existência deste mesmo mundo. Não há um mundo estático e disponível a quem deseja perscrutá-lo. O mundo se forma a partir de cada nova investida que visa conhecê-lo. A língua não articula o mundo "em si", mas a língua articulada é a condição de aparecimento do mundo. Ou ainda: a língua não articula o mundo concreto, mas a "concretude" do mundo se forma a partir da articulação da língua.

\footnotetext{
${ }^{18}$ BENJAMIN, Walter. "O narrador: considerações sobre a obra de Nikolai Leskov". In: BENJAMIN, Walter. Op. cit., p. 197-221.

${ }^{19}$ BENJAMIN, Walter. "O Surrealismo. O último instantâneo da inteligência europeia". In: BENJAMIN, Walter. Op. cit., p. 21-35.

${ }^{20}$ BENJAMIN, Walter. "A imagem de Proust". In: BENJAMIN, Walter. Op. cit., p. 36-49.
} 
III.

Em 26 de julho de 1966, Octavio Paz envia uma carta a Flusser para falar sobre o nada. O escritor mexicano, que já conhecia Língua e Realidade, revela-se extasiado com a leitura de A História do Diabo ${ }^{21}$, de 1965, também publicado originalmente em português. Paz se encanta com a ideia de que somos seres tomados pelo Diabo, ou seja, de que respondemos ao nada que constitui o mundo com as forças diabólicas, fazendo ciência, arte, literatura e filosofia, ao mesmo tempo em que também reconhece, na linha de Flusser, que o Diabo falha se o postulamos como substituto de Deus: "Su libro me ha hecho pensar y, muchas veces, sonreir y hasta reir. Ya sabe usted que la risa es, según Baudelaire, una de las señales del alma caída. En el cielo nadie ríe y, tal vez, tampoco en el infierno. Pero los que estamos en la tierra nos reimos. Estamos endemoniados" 22 .

Paz afirma que o livro diabólico de Flusser coincidia com algo que havia se tornado objeto de suas preocupações: o aparecimento do nada no horizonte da cultura ocidental. A inquietação de Paz não se limitava ao fato de o "nada" ter se convertido em tema da conversação, mas se estendia às possíveis condições de articulação desse nada:

Pero, la nada puede aparecer? No es un contrasentido hablar del descubrimiento de la nada o decir de ella que es la realidad final o la verdad? Apenas se habla de la nada, deja de serlo. Y el silencio tampoco resuelve el problema. Porque el silencio la enuncia, la nombra o la alude y en consecuencia, la nada deja de ser nada, se contagia de $\operatorname{ser}^{23}$.

Estas perguntas partem de alguém que, como Flusser, conhecia os resultados da contaminação do Ocidente pelo nada, e da contaminação do Oriente pelo ser, contaminações estas que não permitiam superar o conflito, mas, ao contrário, traziam-no para o interior: "Nosotros, los occidentales y sus hijos más o menos legítimos de las dos Américas, estamos condenados, me temo, a no salir nunca del ser. No habría un tercer término, más allá, que transcienda a ser y nada?"24.

Paz acompanha o alinhamento teórico de Flusser que toma por inautêntica toda busca por novos sensos de realidade que recorram a culturas que nos são alheias. $O$ desastre do Ocidente, para Flusser, era ter de insistir com um modelo de pensamento que se sabia

\footnotetext{
${ }^{21}$ FLUSSER, Vilém. A História do Diabo. São Paulo: Annablume, 2008.

${ }^{22}$ Carta de Octavio Paz a Vilém Flusser, de 26 de julho de 1966. Inédito. Vilém Flusser Archiv. O contato entre os dois é mediado por Celso Lafer, amigo de Flusser e hoje membro da Academia Brasileira de Letras e professor aposentado do curso de Direito da USP. Flusser o conhece ainda muito jovem, quando Lafer frequenta a sua residência em São Paulo na condição de amigo colegial de sua filha, Dinah. Em 1966, Lafer está nos Estados Unidos para fazer mestrado na Universidade de Cornell e, no primeiro semestre do mesmo ano, Paz atua como professor visitante naquela instituição.

${ }^{23}$ Idem.

${ }^{24}$ Idem.
} 
esgotado. Mas isso também impunha a crítica incansável deste modelo, e a reanálise constante de nossas palavras.

Flusser responde somente mais de um ano depois, em 10 de outubro de 1967. Ele explica, em tom reverente, que a carta de Paz e El laberinto de la soledad estavam sobre sua mesa há quatro meses, mas que relutava em responder por "pudor intelectual" 25 . Ainda assim, responde às inquietações do amigo a partir do seu terreno teórico favorito, a língua e a tradução.

Flusser argumenta que a única forma de forjar um terceiro termo entre o ser e o nada era por meio da tradução, mais precisamente através do que chamava de "meta-termos". A partir desta estratégia, ele preservava um dos termos, o ser, mas substituía o segundo, o nada, pelo meta-termo "dever ser". Aquilo que "deve ser" aparece na possibilidade que temos de valorar a realidade, de produzir cultura. Para Flusser, o nada é uma potência, ou, nos termos de Língua e Realidade, é "dado bruto", "vir-a-ser", "palavras em estado nascente". O nada é uma força, mas uma força não articulável. É uma força que nos impele para o indizível, para que de lá retornemos com palavras. O nada é fundamental, é fundante, mas caminhar em sua direção é perseguir um eu sem fundo.

Traduzir é construir pontes por sobre o abismo. É permitir que o ser toque o nada, que se deixe atravessar pelo nada, sem, contudo, esvaziar-se. Traduzir é deixar-se atravessar pelo nada na medida em que o jogo com as línguas tende a retirar o solo firme sobre o qual nos assentamos, o nosso senso de realidade, a língua vernácula. Tantas são as realidades quantas forem as línguas articuláveis, é uma das máximas de Flusser, definição que impede o estabelecimento de uma única e confiável realidade. Flusser e Paz, que não se conformam nem ao ser e nem ao nada, insistem no "dever ser". Eles persistem com a articulação. Para que o mundo exista, é preciso produzi-lo. E produzir um mundo é exigir que ele seja de um jeito, e não de outro, é forçar que ele "deva ser" de uma forma, é produzir uma forma.

IV.

Em Metafísicas Canibais ${ }^{26}$, Eduardo Viveiros de Castro lembra que a forma de conhecer que se estabeleceu no Ocidente é a da objetivação. Conhecer é reconhecer-se a partir de objetos. É saber diferenciar aquilo que cabe ao objeto daquilo que cabe ao sujeito cognoscente, mas sempre em relação a um elemento externo, a um "de fora" ou a um "isso". O Outro assume a forma da coisa. Para Viveiros, conhecer, em sentido ocidental, é dessubjetivar.

\footnotetext{
${ }^{25}$ Carta de Vilém Flusser a Octavio Paz, de 10 de outubro de 1967. Inédito. Vilém Flusser Archiv.

${ }^{26}$ VIVEIROS DE CASTRO, Eduardo. Metafísicas canibais: elementos para uma antropologia pósestrutural. São Paulo: Cosac Naify, 2015.
} 
Diferente é o caso do xamanismo ameríndio. Para o xamã, conhecer é "personificar", tomar o ponto de vista do outro, antes que o da coisa a ser conhecida. "A forma do Outro é a pessoa. Poderíamos dizer que a personificação ou subjetivação xamânicas refletem uma propensão geral a universalizar a 'atitude intencional' identificada por certos filósofos modernos da mente $[\ldots]^{\prime 27}$.

O xamã covibra com o outro. Sua comunicação é intersubjetiva. Ele se personifica ao assumir o outro como pessoa. Viveiros equipara a personificação xamânica à "atitude intencional" dos filósofos modernos da mente, ou seja, ao conhecimento como um campo relacional dentro do qual sujeitos e objetos são diluídos. Sem grande risco, pode-se identificar esta atitude como referência direta à fenomenologia, bem como supor que entre os "certos filósofos modernos da mente" está não apenas o nome mais evidente, o de Husserl, mas também o de Flusser.

Viveiros toma como pressuposto que a condição original aos humanos e animais não é a animalidade, mas a humanidade ${ }^{28}$. Neste caso, conferir estatuto de pessoa aos seres do mundo não é ceder a desejos antropomórficos, mas, em sentido oposto, garantir dignidade ontológica a tudo o que se pode conhecer e a todos que desejam conhecer. Essa é, segundo ele, uma das molas propulsoras do perspectivismo: "epistemologia constante e ontologias variáveis: mesmas representações, mas outros objetos; sentido único, mas referências múltiplas" ${ }^{29}$.

Viveiros não separa epistemologia e ontologia, mas propõe uma epistemologia prática a partir da ideia de que o conhecedor não representa o conhecido, não o imita, mas interage com ele. O que ele define como "pensamento selvagem" visa, muito além de outra ideia de selvagem, outra ideia de pensamento ${ }^{30}$.

Flusser define o conhecer como elaboração de modelos (vorbild). Mas modelos são articulações linguísticas que não partem do nada. Eles se formam a partir de outros modelos previamente elaborados, aos quais Flusser dá o nome de meta-modelos. É por isso que conhecer, para Flusser, é movimento que passa pela tradução, tanto em razão do fundo plurilíngue dos modelos quanto por ser um modelo tradução de outros modelos. Sobre o tema da tradução, segue Viveiros, em tom muito próximo ao dos pressupostos benjaminianos:

A boa tradução é aquela que consegue fazer com que os conceitos alheios deformem e subvertam o dispositivo conceitual do tradutor, para que a intentio do dispositivo original possa ali se exprimir, e assim transformar a língua de destino. Tradução, traição, transformação. O nome desse processo na antropologia estrutural, como se sabe, é 'mito'31.

\footnotetext{
27 Idem, p. 50.

28 Idem, p. 60.

${ }^{29}$ Idem, p. 68.

30 Idem, p. 74.

${ }^{31}$ Idem, p. 87.
} 
Ao trinômio "tradução, traição e transformação", de Viveiros, equivale o trinômio de Flusser em A História do Diabo: "tentáculos, tentação, tentativa". O crime epistemológico ocidental é o de objetificar o mito, estancá-lo em narrativa definitiva e fechada. Nesta forma congelada de conhecer, os objetos variam, mas o sujeito permanece idêntico e na mesma posição. É uma forma de conhecer que, por temer a alteridade, não se permite alterar-se. Conhecer é traduzir no sentido de garantir ao estrangeiro a hospitalidade sem bloqueios, dando-Ihe a chance de alterar o hóspede.

Linguisticamente, traduzir é jogo com a língua que, mais do que verter um texto de um idioma em outro, perturba em especial a língua de partida do tradutor. Epistemologicamente, traduzir é admitir que o modelo do conhecedor está informado pelos modelos do conhecido. $\mathrm{O}$ esforço de Viveiros de Castro é em demonstrar que a condição tradutiva, intrínseca à antropologia, "discurso conceitualmente codeterminado pelos discursos sobre os quais discorre" ${ }^{32}$, estende-se a todo saber que não se queira objetivo - história, literatura, biologia, filosofia, etc.

V.

Flusser não distingue as ciências pelos assuntos, mas pelos métodos. Por isso os seus ensaios versam sobre temas tão variados e o seu pensamento se coloca em oposição à especialização. Também muitos dos projetos de Benjamin, e o das Passagens é, sem dúvida, o mais grandioso, são consequência menos da escolha de um conteúdo do que da disposição de elementos aparentemente díspares dentro de uma configuração coerente.

As ciências variam segundo os modos como se aproximam dos problemas. Toda ciência pesquisa, procura e busca "algo", mas não convém definir o "real" motivo dessa empreitada. "O que é um gen?", "o que é um antiproton?" e "o que é uma sublimação?" são perguntas não-científicas, conforme Flusser assinala em "Limites borrados"33. A dificuldade em caracterizar esse "algo" ou em classificar esse "sobre" não é defeito da ciência, mas resultado de nosso desespero ontológico.

É custoso admitir que as ciências não falam sobre alguma coisa, que não são objetivas, mas que se constituem em maneiras diferentes de falar. Ainda mais difícil, num segundo momento, é reconhecer que, como são discursivas, as ciências são línguas, e, nesta condição, a física e a biologia se aproximam e se afastam no mesmo sentido em que se tocam e se repelem a língua portuguesa e a língua inglesa. Os limites entre as ciências se borram se estas

\footnotetext{
32 Idem, p. 233.

33 FLUSSER, Vilém. “Limites borrados". In: O’Estado de São Paulo, 19 de setembro de 1964.
} 
são pensadas enquanto língua, já que, assumido o caráter linguístico do conhecimento, a tradução se torna possível, e necessária.

Flusser não encampa a conhecida teoria de que o mundo se apresenta como um livro ou de que o mundo deve ser conhecido como quem lê um texto. Ele propõe que o conhecimento se dá pela articulação de língua. A tese fundamental de Flusser é a de que, a partir do Renascimento, o Ocidente deu preferência ontológica e epistemológica à ciência, e essa fé enganada é a razão do nosso desespero. Os modelos que nos informam, ou seja, os modelos através dos quais conhecemos o mundo, estão imbuídos dos modelos da ciência, por mais que a própria ciência, do final do século XIX em diante, tenha deixado evidente o seu aspecto pouco factível.

Seria preciso perder a fé na ciência, como perderam a fé - tem "má fé" - os que vão ao cinema, pois o fato de reconhecerem que as sombras são mentirosas não lhes retira o prazer da projeção. A ciência não é um caminho preferencial que conduz à "realidade", mas uma das vias pelas quais avança o pensamento: "E uma ontologia intelectualmente aceitável deverá ser formulada, depois de rompida a ligação entre ciência e fé, em base do caráter linguístico do conhecimento, do qual o conhecimento científico é apenas um aspecto" ${ }^{34}$.

VI.

Um exemplo em que a ciência perde terreno em benefício da ficção é a leitura de Flusser do Grande Sertão: Veredas, de Guimarães Rosa, de quem foi amigo. Em "Guimarães Rosa e a Geografia"35, Flusser contrapõe, como o título do ensaio indica, o sertão de Rosa, que não está no mapa, e o sertão da geografia, versão científica que aparece nas cartografias. 0 planalto, como Flusser também chama o sertão, não tem um ponto de culminância, um Monte Sinai, que revelaria o ser enquanto Deus, mas tem "nonada", a manifestação do ser enquanto Diabo, que teima em ser e que aniquila.

O sertão é indescritível, isto é, não cabe na geografia. Ele despreza "soberanamente" toda dimensão humana. A vivência do sertão é, neste sentido, a aniquilação do homem enquanto medida de todas as coisas, mais violenta, de acordo com Flusser, do que a sofrida na contemplação do céu estrelado. A vivência do planalto não é a experiência do vazio, mas do incomensurável. Um vazio é, em certa medida, um espaço sem nada, um oco, um buraco aberto no dentro, uma forma sem conteúdo. Um vazio é um espaço contornado. Mas um espaço sem nada não é um nonada. O que o sertão substantiva não é uma medida absoluta, mas a absoluta falta de medida. Ele não prova que o ser está vazio, mas impossibilita toda forma, segura, de ser:

\footnotetext{
${ }^{34}$ Ibidem.

${ }^{35}$ FLUSSER, Vilém. “Guimarães Rosa e a Geografia”. In: Comentário, 1 de outubro de 1969.
} 
A sua imensidão (no sentido de "falta de medida") resulta em desorientação e vertigem, portanto em terror e exaltação desenraizadora. A Masslosigkeit (imensidão) resulta em Bodenlosigkeit (falta de fundamento). Não se pode habitar o sertão, no sentido de habituar-se a ele. O sertanejo, qual marinheiro, vive em situação exposta e sem fundamento, não mora. Viver assim é muito perigoso. Mas o marinheiro visa o porto como sentido da travessia, e o sertanejo atravessa sem sentido nem meta. As ondas do mar embalam o marinheiro com seu ritmo articulado enquanto as ondas paradas do sertão, as suas inarticuladas colinas, envolvem o sertanejo em monotonia imóvel. Um mar congelado, sem definição, um campo de ondas paradas (em sentido próximo ao sentido visado por esta expressão pela física da atualidade) $)^{36}$.

Flusser reforça que Rosa não apenas confirma a sua teoria da tradução, como a aproxima da sua teoria do desterramento ou da falta de fundamento (bodelonsigkeit). Ele assume o "nonada", para além da descrição de uma paisagem, como um princípio de pensamento. Estar nonada é sentir-se sempre fora de casa, exposto, sem chão. É não ter origem ou meta. É admitir que o pensamento não tem um fim: um final e uma finalidade.

A comparação entre o sertanejo e o marinheiro leva à comparação entre o sertão e o mar. O fundo do mar também não tem dimensão. O "fundo" do oceano não é, como se costuma dizer de um "fundo", o local onde tudo termina. É um fundo que se traduz melhor por um profundo, nos moldes em que se discute a profundidade da alma. O fundo do mar não se mede em metros ou quilômetros. A profundidade não tem medida. A imagem que temos do fundo do mar não é a da terra firme, mas a da precipitação dos objetos, das joias, dos fitoplânctons, dos corpos, das embarcações. O fundo do mar é um cair constante. Não um fundo, mas um afundar no abismo.

Vinte anos depois da publicação do ensaio sobre o sertão, Flusser publica o Vampyroteuthis Infernalis ${ }^{37}$, em 1987, e repetirá textualmente, mas desta vez referindo-se ao fundo do oceano, "que não se pode habitar o abismo, no sentido de habituar-se a ele". 0 habitat do polvo, personagem desta "ficção filosófica" (segundo a definição de Abraham Moles), é inabitável ao homem, mas, se este não pode habitar o inabitável, pode tentar habituar-se ao inabitual. O sertanejo não mora, mas homem nenhum mora no mundo. 0 homem nunca está em casa, e é preciso sair de casa para conhecer o mundo. É por isso que o vampyroteuthis, essa "Iula-molusco-do-inferno", mais do que um monstro que habita o abismo do oceano, é o Outro do homem, é o que o homem teve de recalcar para que a civilização se tornasse possível.

Gustavo Bernardo recorda que os cephalopoda, como é o vampyroteuthis, "são animais-redemoinhos com respiração e locomoção sincronizadas" ${ }^{38}$. O Diabo está no redemoinho - nonada e vampyroteuthis. Os redemoinhos se formam no sertão e no fundo do

\footnotetext{
${ }^{36}$ Ibidem.

${ }^{37}$ FLUSSER, Vilém. Vampyroteuthis Infernalis. São Paulo: Annablume, 2011. A primeira edição, de 1987, foi publicada em alemão. A edição de 2011, publicada em português, foi redigida pelo próprio Flusser. ${ }^{38}$ BERNARDO, Gustavo. A dúvida de Flusser. São Paulo: Globo, 2002.
} 
mar. As formas se formam na imensidão e no incomensurável. "A procura da melhor deformação é, por paradoxal que pareça, a procura da melhor forma: busca-se menos a forma do rosto do que a sua melhor sombra" ${ }^{39}$. A tentativa da arte abstrata, prossegue Gustavo, foi a de fundar um mundo sem tato, sem gesto, a de ousar falar sobre o que não se pode articular, a "forma fundando forma" 40 .

Foram as tentativas de Flusser e Rosa, mas estes não se dispuseram tanto a fundar um mundo sem gesto, e sim a dar sentido ao mundo a partir dos gestos. E isso passava pela gestação de formas, isto é, menos pela busca de uma forma original do que pelo mergulho no inarticulável onde as formas são gestadas. Flusser explica que forma, em grego, é morphé, e belo, morphéeis. A forma e a beleza são denominadas com a mesma palavra: "Em português ainda se diz "formoso". Uma bela ilha é Formosa"41.

Esta era a formosura da língua imaginada por ambos. Não a procura pela palavra que melhor descrevesse a vida, mas a articulação de uma estrutura de pensamento linguística que estivesse à altura da complexidade da vida. A palavra alemã wirklichkeit, traduzida usualmente como "realidade", é, aponta Flusser, a tentativa de tradução do conceito latino efficientia, e não do termo realitas, pois o verbo wirken implica "levar a efeito", "fazer ou ter efeito". A palavra alemã para realidade, portanto, está muito mais próxima da efetividade. A vida não é, ela pode ser ${ }^{42}$.

Em carta a Milton Vargas, de 25 de janeiro de 1975, Flusser discorda do amigo, para quem a forma era algo que se manifestava nos fenômenos e que poderia ser descoberta de acordo com uma nova metafísica. Ele reafirma que forma é como os fenômenos se manifestam. O formalismo, enquanto estudo de formas vazias, não era uma metafísica, mas uma disciplina que tinha por objetivo as virtualidades e as potencialidades. Flusser tomava por desonesto todo pensamento formal que assumisse, religiosamente, o "ser-em-si" em detrimento do "ser assim":

Creio que é isto o que caracteriza o verdadeiro pensamento formal: libertarse do preconceito da forma perfeita (do círculo, da simetria, do sistema consistente etc.), e estudar as formas imperfeitas, complexas, contraditórias e aproximadas que são como as coisas se dão efetivamente ${ }^{43}$.

Fuga das formas perfeitas, rechaço das simetrias, das circularidades, dos contornos, dos sistemas. Estudo das formas imperfeitas, complexas, moventes e se-mexentes (as garças de Rosa), como são as formas da vida.

\footnotetext{
${ }^{39}$ Idem, p. 86.

${ }^{40}$ Idem, p. 245.

${ }^{41}$ FLUSSER, Vilém. Comunicologia: reflexões sobre o futuro: as conferências de Bochum. Trad. Tereza Maria Souza de Castro. São Paulo: Martins Fontes, 2014, p. 83.

${ }^{42}$ Em conotação mais restrita, há, em alemão, a palavra realität.

${ }^{43}$ Carta de Vilém Flusser a Milton Vargas, de 25 de janeiro de 1975. Inédito. Vilém Flusser Archiv.
} 
VII.

O Vampyroteuthis Infernalis, livro que talvez melhor resuma a proposta intelectual de Flusser, pode ser visto, preservando a etimologia irônica do seu autor, como um "tratado" sobre o conhecimento, um discurso sobre o método. Flusser elabora uma teoria do conhecimento a partir de uma fábula a respeito de um polvo, de existência factual cientificamente comprovada, mas reinventa suas características fisiológicas e comportamentais.

Com esse gesto, Flusser reúne, no Vampyroteuthis, a tradição do Fausto (Diabo) e a tradição barroca do monstro (bestiários). Mais do que isso, seu "tratado" confirma que ambas as tradições não estão separadas. O monstro, neste caso o polvo, desempenha o papel do Outro, da alteridade radical, do animal pegajoso que habita o abismo e que circula pelo espaço subterrâneo que o homem não pode adentrar sem se colocar em risco. O polvo é o animal que não se deixa apreender e que, em contrapartida, apreende seu desafiante por todos os lados. O Diabo, neste caso Mefistófeles, é o alerta constante que indica ao homem que a completude é inalcançável.

Na linha vertical que tem no homem o ponto central, o vampyroteuthis infernalis está no extremo inferior. Ele habita o abismo do fundo do oceano. Vive em noite eterna, interrompida pelos jatos de tinta colorida que ele mesmo lança na água, capazes de provocar verdadeiros shows pirotécnicos, festas fugazes em tecnicolor. $\mathrm{O}$ ambiente é erótico e violento. Sua existência se divide entre orgias sexuais, canibalismo intraespecífico e devoração de seres inferiores.

O mundo do octópode não é fenomenal, como o nosso. Ele percebe apenas os fenômenos de seu próprio interesse. O que lhe aparece, aparece apenas em razão da projeção luminosa de sua sépsia. Do mesmo modo, a comunicação e a arte deste ser tentacular não são objetivas, ou seja, não passam pela manipulação de materiais e objetos. O vampyroteuthis transmite informações ao colorir a superfície da água e ao colorir a superfície do próprio corpo. O mundo do vampyroteuthis é mundo codificado. Todos os seus gestos - artísticos, sexuais, comunicativos - são resultado da manipulação de códigos e símbolos. Mais precisamente da preparação de artimanhas que visam atrair, mas quase sempre enganar, seus parceiros de espécie.

Mas como conhecer o vampyroteuthis? O homem habita na superfície, e não poderia suportar a pressão das profundezas do oceano. O vampyroteuthis habita no fundo do mar, e também não aguentaria ascender à superfície. $O$ encontro entre homem e vampyroteuthis é impossível, a não ser que o octópode fosse trazido ao laboratório morto, o que tornaria o encontro desinteressante.

Conhecer o vampyroteuthis implicaria desvendar os códigos de sua linguagem, mas o nosso acesso a este código é limitado, pois não nos comunicamos diretamente com o bicho. 
O que podemos fazer é tentar captar o clima (stimmung) dentro do qual opera a linguagem do animal, dentro do qual ele vive, depreender os "efeitos de sentido" de suas expressões.

Para Flusser, conhecer o vampyroteuthis não era sugerir ao homem que se "vampyroteuthizasse". Ele repugnava o que se poderia chamar de "biologismo epistemológico", tendo em vista o horizonte fascista que comandava este tipo de opção investigativa, mesmo horizonte que levava Benjamin a duvidar da empatia enquanto método viável para a crítica da história, dada a tendência quase inercial dos agentes analíticos de identificar-se com os vencedores. Para Flusser, o assunto de toda conversação humana é sempre o homem. O vampyroteuthis, nosso antípoda na cadeia natural, cumpriria o papel de modelo (nos termos de Flusser) para o homem. Modelo que permitiria ao homem abandonar a história e, ao mesmo tempo, ingressar na pós-história com cautela. Flusser está menos preocupado, portanto, em saber como é "ser" um vampyroteuthis do que em sacar, a partir do bicho, um modelo de existência (sexual, social, cultural, artístico) que possibilite criticar os nossos próprios modelos.

Não seria essa a questão epistemológica mais fundamental, quer dizer, como conhecer qualquer coisa sem ter que, para isso, assassiná-la? Como captar o pensamento em movimento? Como traduzir o mundo em símbolos, tendo em vista, ao mesmo tempo, que o mundo não preexiste a estes processos de simbolização?

VIII.

Conhecer pode ser, portanto, sinônimo de traduzir. Todavia, conhecer não é descrever fenômenos que supostamente ocorrem no mundo. O exemplo do vampyroteuthis interessa sobretudo neste ponto: o mundo do octópode não é fenomênico, isto é, as coisas apenas aparecem no abismo do oceano quando o próprio bicho lança a sépsia na água. Aquilo que aparece não se separa, assim, das categorias de pensamento daquele que as faz aparecer. Tal característica do processo epistemológico está presente, como se viu, no perspectivismo de Eduardo Viveiros de Castro.

A eficiência da teoria não está na sua maior ou menor capacidade em detalhar o funcionamento dos seres e da natureza, mas em dispor os seres e a natureza de modo particular. A teoria não explica o mundo, ela o reconfigura, assim como cada investimento de compreensão da história reabre os eventos históricos aparentemente ocorridos e encerrados no passado. 
No conhecido "A tarefa do tradutor"44, Benjamin postula que "a tradução é uma forma" 45 . Traduzir é transformar o simbolizante no próprio simbolizado. Para Benjamin, não cabe ao tradutor captar o significado do texto original, mas depreender o seu modo de designar. Em igual modo, Flusser afirma que era impossível ao homem decifrar a linguagem do vampyroteuthis, sendo mais proveitosa a tentativa de imaginar o clima dentro do qual habita o animal. O caso de Guimarães Rosa, se corroboramos a leitura de Flusser, é o mesmo: o "nonada" não é uma descrição do sertão, que se define pela imensidão, mas uma imagem ou uma estratégia literária-epistemológica que permite imaginar a vida dentro da imensidão. Benjamin, no ensaio supracitado, aproxima a teoria da tradução a uma teoria do conhecimento justamente quando afasta a validade do método imitativo:

\begin{abstract}
Para apreender a autêntica relação entre original e tradução teremos de encetar uma reflexão cujo propósito é em tudo análogo à argumentação pela qual a crítica do conhecimento demonstra a impossibilidade de uma teoria da imitação. Nesta, mostra-se que no processo de conhecimento não poderia haver objectividade, nem sequer a pretensão disso, se ele consistisse em captar cópias do real; do mesmo modo podemos demonstrar que nenhuma tradução seria possível se a sua aspiração, a sua essência última, fosse a da semelhança com o original ${ }^{46}$.
\end{abstract}

Desprezar uma teoria da tradução ou do conhecimento que se baseie na imitação não significa, como se viu, desprezar o elemento factual. Significa, em outros termos, postular que não há objetividade quando se trata de conhecer o mundo. Em Origem do drama barroco alemão ${ }^{47}$, Benjamin explica que o trabalho da filosofia é o de mostrar que a função das formas da arte é "converter em conteúdos de verdade, de caráter filosófico, os conteúdos factuais, de caráter histórico, que estão na raiz de todas as obras significativas" 48 . Em consonância com a teoria da língua de Flusser, Benjamin não sugere que se ignore o elemento factual, mas admite que o trabalho do historiador e do tradutor é o de articular esse elemento na forma de língua ou imagem, tornando-o acessível à crítica filosófica.

No mesmo livro, Benjamin assinala que o alegórico permite que cada pessoa, coisa ou relação possa significar qualquer outra, o que conduz a um desprezo pelo mundo profano, no qual o pormenor não tem importância. Ao mesmo tempo, o fato de apontarem para além deles mesmos investem estes suportes de significação de um poder que os faz aparecer incomensuráveis frente às coisas profanas, elevando-os a um plano mais alto. Se Flusser

\footnotetext{
${ }^{44}$ BENJAMIN, Walter. "A tarefa do tradutor". In: CASTELLO BRANCO, Lucia (org.). A tarefa do tradutor, de Walter Benjamin: quatro traduções para o português. Trad.: João Barrento ("A tarefa do tradutor). Belo Horizonte: UFMG, 2008.

${ }^{45}$ Idem, p. 83.

${ }^{46}$ Idem, p. 86.

47 BENJAMIN, Walter. Origem do drama barroco alemão. Trad. Sérgio Paulo Rouanet. São Paulo: Brasiliense, 1984. A obra, cujo título em alemão é Ursprung des deutschen Trauerspiels, foi traduzido também ao português, por João Barrento, como Origem do drama trágico alemão.

${ }^{48}$ Idem, p. 204.
} 
aproxima tradução e religião na medida em que ambas discutem o sentido e o sem-sentido do mundo, Benjamin avalia que, na perspectiva alegórica, "o mundo profano é ao mesmo tempo exaltado e desvalorizado"49: "A dialética da convenção e da expressão é o correlato formal dessa dialética religiosa do conteúdo. Pois a alegoria é as duas coisas, convenção e expressão, e ambas são por natureza antagonísticas" ${ }^{50}$.

Embora aparentemente antagonistas, a convenção e a expressão tornaram-se, no barroco, uma coisa só, criada, da mesma forma que a escrita sagrada. Esta questão também se apresenta na troca de cartas entre Flusser e Octavio Paz. Entre o ser e o nada, entre a essência totalizante e o silêncio, cumpre inserir o deve ser, tão característico dos gestos artísticos. Conhecer não é adequação de forma e conteúdo - res e res extensa. E traduzir não é estabelecer uma relação entre original e cópia. Traduzir, na esteira de Benjamin, seria representar a própria convenção. Fazer da convenção o tema central da conversação. Numa sociedade como a brasileira, que parece ter perdido toda possibilidade de estabelecer consensos, pensar a tradução enquanto teoria do conhecimento é tarefa política urgente.

\section{Referências}

BENJAMIN, Walter. A obra de arte na era de sua reprodutibilidade técnica. In: BENJAMIN, Walter. Magia e técnica, arte e política: ensaios sobre literatura e história da cultura. Trad. Sergio Paulo Rouanet. São Paulo: Brasiliense, 1994, p. 165-196.

BENJAMIN, Walter. Sobre o conceito de História. In: BENJAMIN, Walter. Magia e técnica, arte e política: ensaios sobre literatura e história da cultura. Trad. Sergio Paulo Rouanet. São Paulo: Brasiliense, 1994, p. 222-234.

BENJAMIN, Walter. O narrador: considerações sobre a obra de Nikolai Leskov. In: BENJAMIN, Walter. Magia e técnica, arte e política: ensaios sobre literatura e história da cultura. Trad. Sergio Paulo Rouanet. São Paulo: Brasiliense, 1994, p. 197-221.

BENJAMIN, Walter. O Surrealismo. O último instantâneo da inteligência europeia. In: BENJAMIN, Walter. Magia e técnica, arte e política: ensaios sobre literatura e história da cultura. Trad. Sergio Paulo Rouanet. São Paulo: Brasiliense, 1994, p. 21-35.

BENJAMIN, Walter. Origem do drama barroco alemão. Trad. Sérgio Paulo Rouanet. São Paulo: Brasiliense, 1984.

BENJAMIN, Walter. A tarefa do tradutor. In: CASTELLO BRANCO, Lucia (org.). A tarefa do tradutor, de Walter Benjamin: quatro traduções para o português. Trad.: João Barrento ("A tarefa do tradutor). Belo Horizonte: UFMG, 2008.

BENJAMIN, Walter. A imagem de Proust. In: BENJAMIN, Walter. Magia e técnica, arte $e$ política: ensaios sobre literatura e história da cultura. Trad. Sergio Paulo Rouanet. São Paulo: Brasiliense, 1994, p. 36-49.

\footnotetext{
${ }^{49}$ Idem, p. 197.

50 Ibidem.
} 
BERNARDO, Gustavo; GULDIN, Rainer. O homem sem chão. A biografia de Vilém Flusser. São Paulo: Annablume, 2017.

BERNARDO, Gustavo. A dúvida de Flusser. São Paulo: Globo, 2002.

Carta de Octavio Paz a Vilém Flusser, de 26 de julho de 1966. Inédito. Vilém Flusser Archiv.

Carta de Vilém Flusser a Octavio Paz, de 10 de outubro de 1967. Inédito. Vilém Flusser Archiv.

Carta de Vilém Flusser a Milton Vargas, de 25 de janeiro de 1975. Inédito. Vilém Flusser Archiv.

DERRIDA, Jacques. Seminario La bestia y el soberano: volumen 2001-2002. Trad. Cristina de Peretti e Delmiro Rocha. Buenos Aires: Manantial, 2010.

FLUSSER, Vilém. Língua e Realidade. São Paulo: Annablume, 2007.

FLUSSER, Vilém. Filosofia da Caixa Preta: ensaios para uma futura filosofia da fotografia. São Paulo: Annablume, 2011.

FLUSSER, Vilém. Comunicologia: reflexões sobre o futuro: as conferências de Bochum. Trad. Tereza Maria Souza de Castro. São Paulo: Martins Fontes, 2014.

FLUSSER, Vilém. Bodenlos: uma autobiografia filosófica. São Paulo: Annablume, 2007.

FLUSSER, Vilém. Da tradução. In: Cadernos Brasileiros, São Paulo, outubro de 1968.

FLUSSER, Vilém. A História do Diabo. São Paulo: Annablume, 2008.

FLUSSER, Vilém. Problemas da tradução. Inédito. Vilém Flusser Archiv.

FLUSSER, Vilém. Guimarães Rosa e a Geografia. In: Comentário, 1 de outubro de 1969.

FLUSSER, Vilém. Até a terceira e quarta geração. Vilém Flusser Archiv.

FLUSSER, Vilém. Exílio e criatividade. In: Viagem Brasileira, novembro de 1984.

FLUSSER, Vilém. Vampyroteuthis Infernalis. São Paulo: Annablume, 2011.

https://doi.org/10.14195/978-989-26-1128-0

FLUSSER, Vilém. Limites borrados. In: O’Estado de São Paulo, 19 de setembro de 1964.

FOUCAULT, Michel. A ordem do discurso. Trad.: Laura Fraga Sampaio. 21 ed. São Paulo: Loyola, 1996.

GULDIN, Rainer. Pensar entre línguas: a teoria da tradução em Vilém Flusser. Trad. Murilo Jardelino e Clélia Barqueta. São Paulo: Annablume, 2010.

RANCIÈRE, Jacques. O mestre ignorante: cinco lições sobre a emancipação intelectual. Trad. Lílian do Valle. Belo Horizonte: Autêntica, 2002.

VAIHINGER, Hans. A filosofia do como se: sistema das ficções teóricas, práticas e religiosas da humanidade, na base de um positivismo idealista Trad. Johannes Kretschmer. Chapecó: Argos, 2011.

VIVEIROS DE CASTRO, Eduardo. Metafísicas canibais: elementos para uma antropologia pósestrutural. São Paulo: Cosac Naify, 2015. 